Original Research Paper

\title{
Identification of Diseases and Pests of Cauliflower (Brassica oleracea) in the Pedan Hamlet Plantation, Karanglo, Tawangmangu
}

\author{
Fety Fatimah $^{1 *}$, Hidayatun Nurul Khasanah ${ }^{1}$, Rif' atin Khoirunnisa ${ }^{1}$, Farhah \\ Qurrotu'Aini ${ }^{1}$, Nur Rokhimah Hanik ${ }^{1}$ \\ ${ }^{1}$ Biology Education Study Program, Faculty of Teacher Training and Education, University of Veteran \\ Bangun Nusantara Sukoharjo
}

\author{
Article History \\ Received : November $25^{\text {th }}, 2021$ \\ Revised : December $05^{\text {th }}, 2021$ \\ Accepted : December $20^{\text {th }}, 2021$ \\ Published : January $05^{\text {th }}, 2022$ \\ *Corresponding Author: \\ Fety Fatimah, \\ Biology Education Study \\ Program, Faculty of Teacher \\ Training and Education, \\ University of Veteran Bangun \\ Nusantara Sukoharjo ; \\ Email: \\ Fetyfatimah120201@gmail.com
}

\begin{abstract}
Cauliflower (Brassicca oleracia var.brotrytis L.) is a type of vegetable that belongs to the Brassicaceae family (a type of cabbage with small white flowers). The purpose of the research on cauliflower (Brasica oleracea var. Botrytis L.) was to identify pests and diseases that attack cauliflower (Brasica oleracea var. Botrytis L.). The method used in this study was to go directly to the field once in August 2021. Observations were made on agricultural land owned by farmers in Pedan Hamlet, Karanglo Village, Tawangmangu, Karanganyar. The results showed that from three different land samples, different pests and diseases were encountered. In the first land sample, several pests were found such as grasshoppers, capers, spiders, and cauliflower caterpillars (Plutella xylostella) while the diseases that attacked were some cauliflower affected by whip tail disease, but very many cauliflower plants were found that were attacked by black rot and soft. In the second land sample, the most common pests found were capers, third field mop spiders, and the pests encountered were grasshoppers, spiders, capers and caterpillars and cauliflower caterpillars. While the disease that attacks is whiptail disease. In conclusion, the average pests that attack cauliflower plants are capers, spiders, cauliflower caterpillars and grasshoppers. And the common diseases that attack cauliflower plants are black rot, soft rot and whip tail.

Keywords: Cauliflower (Brasica oleracea var. Botrytis L.), Pests, Diseases.
\end{abstract}

\section{Pendahuluan}

Bunga kol (Brassicca oleracia var.brotrytis L.) adalah jenis sayuran yang termasuk dengan famili Brassicaceae (jenis kol dengan bunga putih kecil). Masyarakat Indonesia bisa menyebutnya kubis bunga atau white curd). Pada dasar kepala tersebut terdapat daun daun hijau yang tebal dan tersusun rapat. Kubis bunga juga mirip dengan kubis romanesco. Bunga kol merupakan sumber vitamin dan mineral dan lazimnya dimakan dengan di masak terlebih dahuludahulu, meskipun dapat di makan mentah atau di buat acar (Utomo. 2015). Kubis bunga (botytris) merupakan jenis sayuran yang memiliki banyak manfaat bagi kesehatan, seperti mengatasi gangguan pencernaan, mencegah efek radiasi ultraviolet, diabetes,radang usus, degenerasi macula, obesitas dan hipertensi. Sumber vitamin C (asam askorbat), folat, vitamin K (Phylloquinone) dan vitamin B6. Vitamin B1 (tiamin), B2 (riboflapin), B3 (niasin) dan sejumlah kecil vitamin E (alfa-tokoferol). Kubis bunga juga menyediakan mineral penting seperti kalsum, magnesium, fosfor, kalium dan mangan tanpa klestrol berbahaya. Merupakan sumber protein, dan dengan sumber lemak jenuh yang sangat rendah. Daripada lemak-lemak tak jenuh dan asam omega-3 lemak esensial yang bermanfaat.kandungan serat dan gula alami kubis bunga lebih rendah jika dibandingkan dengan brokoli (Anonim. A, 2009)

Tingginya produksi bunga kol sangat tergantung dengan kwalitas hasil panen, terutama pada massa bunganya. Kendala yang ditemui sehingga mengakibatkan penurunan kwalitas bunga kol pada umumnya disebabkan oleh hama serangga dan penyakit, sehingga mutu dan harganya merosot (Galuh, 2012). Salah satu penyebab dari penurunan ini adalah meningkatnya serangan patogen penyebab penyakit yang berakibat pada gagal 
panen.Penyakit yang sering menyerang bunga kol adalah penyakit busuk hitam yang disebabkan oleh bakteri Xanthomonas camprestis Dows dan penyakit busuk lunak oleh bakteri Erwinia carotovora Holland (Wulansari, 2015). Busuk lunak menginfeksi tanaman di kebun dan pasca panen. Infeki terjadi melalui luka pada pangkal bunga yang hampir di panen atau melalui akaryang terluka. Batang atau masa bunga yang terserang akan menjadi busuk sehingga tanaman tidak dapat di panen. Selain itu ada beberapa hama yang menggangu pertumbuhan bunga kol seperti ulat, kaper, belalang dan laba-laba. Berbagai langkah dikembangkan untuk pengendalian terhadap penyakit "busuk lunak" yang telah dilakukan untuk meningkatkan produksi bunga kol dan untuk mencegah penyebaran penyakit serta kembali bakteri padainang yang terinfeksi. Penerapan pengendalian penyakit dapat dilakukan secara fisik ataupun kimia, namun penerapan praktis berbagai teknik seringkali berdampak negatif terhadap kesehatan manusia dan lingkungan, selain itu harganya tergolong mahal (Sastrisiswojo, 2015). Sekarang ini telah banyak ditemukan agen-agen hayati yang tidak hanya mengendalikan penyakit tanaman, tetapi juga dapat mempengaruhi pertumbuhan tanaman (Soesanto, 2011). Mikroorganisme yang bersifat antagonis seperti Psedumonas fluorescens yang di laporan efektif mengendalikan penyakit layu bakteri Ralstonia solanacearum pada tanaman kentang (Soesanto, 2011) dan Tricorderma sp. yang juga efektif mengendalikan beberapa penyakit, misalanya hawar daun bakteri (Xantomonas oryzae pv oryzae) pada tanaman padi (Damanik, 2013).

Hama maupun penyakit pada tanaman kubis bunga kerap muncul dan menimbulkan kerusakan, mengurangi produksi bahkan dapat menyebabkan gagal panen. Beberapa hama dan penyakit ini dapat menyebar ke jaringan tanaman lain dengan cepat, sehingga petani harus mengantisipasi serangannya dengan seksama. Dalam penelitian ini hama dan penyakit yang ditemui adalah Crysodeixis chalcites (Esp.), Plutella maculipennis, penyakit Xhanthomonas campestris Dows (Sunarti, 2017). Tanaman bunga kol yang terserang oleh patogen penyakit penyebab busuk lunak mengalami pembusukan pada saat tananaman mulai pembentukan bunga, dengan memperhatikan gejala awal daun terliat menguning seperti terbakar. Sedangkan pada bunga kol yang sudah terbentukmulai berwarna gelap sampai membusuk. Kondisi ini terjadi karena di dukung dengan tingginya curah hujan (Runtuhaku, 2016). Penyakit penting yang sering menyerang tanaman brokoli adalah penyakit busuk hitam yang disebabkan oleh bakteri Xhantomonas campestris Dows. Yang berakibat pada penurunan poduksi brokoli dan gagal panen. Infeksi tanaman oleh bakteri ini menyebabkan batang atau massa bunga yang terserang menjadi busuk berwarna hitam atau coklat sehinga tanaman tidak dapat dipanen. Gejala khas di daun pada tanaman busuk hitam yang dapat membedakannya pada penyakit lain adalah bercak kuning berbentuk $\mathrm{V}$. bercak ini kemudian dapat menyebar ke seluruh daun tanaman. Bakteri dapat pula menyebaban pembuluh menghitam, pengangktan nutrisi terhambat, dan korp hitam (Fei Sie L. dkk, 2016)

Berdasarkan permasalahan diatas dan mengingat tanaman bunga kol menjadi tanaman penting karna bukan saja sebagai sayur-sayuran namun ada mengonsumsi sebagai obat, maka penelitian ini dilakukan untuk mengidentifikasi secara jelas jenis hama dan penyakit yang menyerang sayur bunga kol. Tujuan dari penelitian ini adalah untuk mengetahui macam hama dan penyakit yang menyerang tanaman kol bunga (Brasica oleracea var.Botrytis L.) serta dapat mengidentifikasi brbagai jenis hama dan penyakit yang umumnya menyerang tanaman kol bunga (Brasica oleracea var. Botrytis L.). Penelitian ini bermanfaat memberikan informasi mengenai hama dan penyakit yang umumnya menyerang tanaman kol bunga (Brasica oleracea var. Botrytis L.) sehingga dapat menjadi bahan pertimbangan dalam upaya pengendalian yang efektif.

\section{Bahan dan Metode}

\section{Waktu dan Lokasi}

Kegiatan penelitian ini dilaksanakan pada tanggal 2 Agustus 2021. Kegiatan penelitian ini dilaksanakan di perkebunan Dusun Pedan, Desa Karanglo, Tawangmangu Karanganyar. Desa Karanglo terletak di kaki gunung lawu yang berada di ketinggian 600-650 mdpl. Pada saat kegiatan penelitian suhu mencapai 22 derajat celcius. 


\section{Bahan dan Alat}

Kegiatan penelitian ini menggunakan beberapa alat pendukung, diantaranya seperti kamera untuk mengambil gambar dan alat tulis untuk mendata, dan dengan sampel 3 petak lahan sayur bunga kol.

\section{Teknik Pengumpulan Data}

Teknik ini menggunakan metode Observasi langsung dan wawancara pada pemilik kebun bunga kol. Data dianalisis dengan deskripsi kualitatif. Variabel yang diamati dalam penelitian ini yaitu hama dan penyakit yang ditimbulkan pada sayur bunga kol.

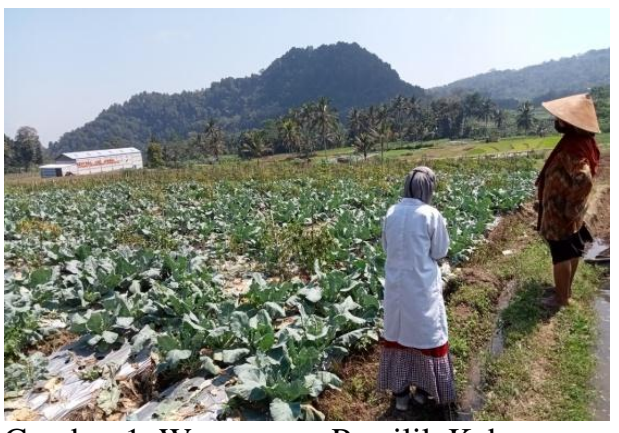

Gambar 1. Wawancara Pemilik Kebun

Kegiatan wawancara dilaksanakan denganmencari sumber informasi kepada pemilik kebun bunga kol dengan tujuan mencari serta memperkuat data tambahan yang diperoleh dari kegiatan observasi.

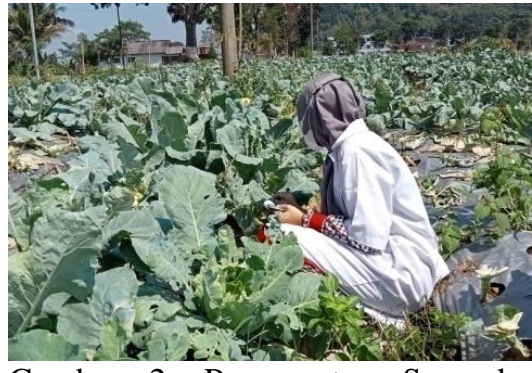

Gambar 2. Pengamatan Sampel Lahan 1

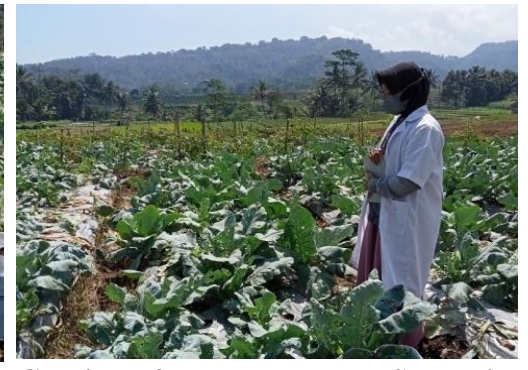

Gambar 3. Pengamatan Sampel Lahan 2

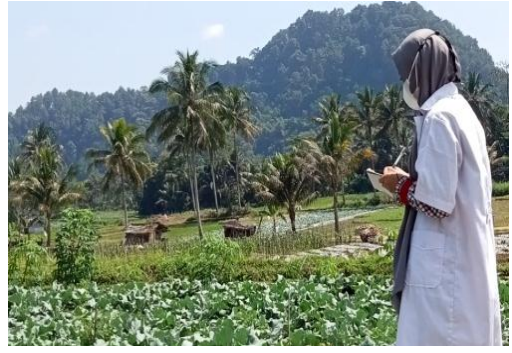

Gambar 4. Pengamatan Sampel Lahan 3

\section{Tahapan Penelitian}

Tahapan pada penelitian ini meliputi Menentukan jenis tananam yang akan diamati, dan lokasi untuk penelitian. Menyiapkan alat dan bahan yang akan digunakan dalam penelitian. Selanjutnya pelaksanakan penelitian, dengan observasi dan memperoleh data dari wawancara serta mendokumentasikan penelitian. Kemudian enganalisis hasil dan membuat laporan penelitian. Dan yang terakhir yaitu menyimpulkan macam-macam hama dan penyakit pada tanaman bunga kol.

\section{Hasil dan Pembahasan}

Dari kegiatan penelitian di Perkebunan Dusun Pedan, Karanglo, Tawangmangu. Kami mendapatkan hasil seperti tabel dibawah ini:

Tabel 1. Hasil penelitian

\begin{tabular}{|c|c|c|c|}
\hline No & Petak/lahan & Hama & Penyakit \\
\hline 1 & Sampel lahan 1 & $\begin{array}{l}\text { - Belalang } \\
\text { - Kaper } \\
\text { - Laba-laba } \\
\text { - Ulat Bunga Kol (Plutella xylostella) }\end{array}$ & $\begin{array}{ll}\text { - } & \text { Ekor cambuk } \\
\text { - } & \text { Busuk lunak } \\
\text { - } & \text { Busuk hitam }\end{array}$ \\
\hline 2 & Sampel lahan 2 & $\begin{array}{l}\text { - Ulat Bunga Kol (Plutella xylostella) } \\
\text { - Kaper } \\
\text { - Laba-laba }\end{array}$ & $\begin{array}{ll}\text { - } & \text { Ekor cambuk } \\
\text { - } & \text { Busuk lunak } \\
\text { - } & \text { Busuk hitam }\end{array}$ \\
\hline 3 & Sampel lahan 3 & $\begin{array}{l}\text { - Belalang } \\
\text { - Kaper } \\
\text { - Ulat Bunga Kol (Plutella xylostella) }\end{array}$ & - $\quad$ Ekor cambuk \\
\hline
\end{tabular}




\section{Survai Lokasi}

Kegiatan penelitian identifikasi jenis penyakit pada sayuran bunga kol dilaksanakan di Dusun Pedan, Desa Karanglo, Tawangmangu Karanganyar. Kegiatan penelitian ini dilaksanakan selama 1 hari pada tanggal 2 Agustus 2021. Proses identifikasi gejala hama dan penyakit pada sayuran bunga kol dilakukan dengan observasi dan penelitian beberapa sayuran bunga kol yang berada di daerah Kecamatan Tawangmangu. Terdapat 2 kondisi bunga kol yang pertama tidak terserang oleh hama dan penyakit seedangkan yang keduat terserang hama dan penyakit bisa dilihat di gambar 5 dan 6 di bawah ini:

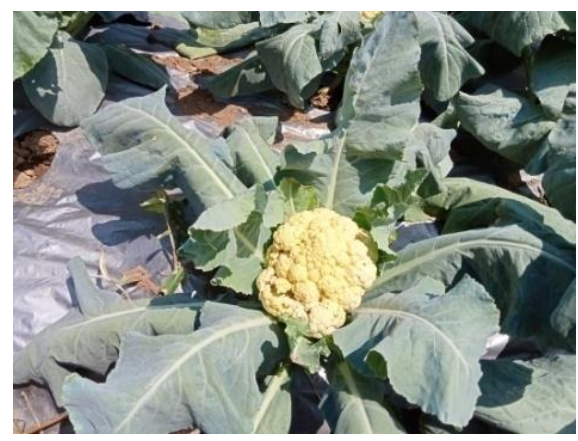

Gambar 5. Kondisi Bunga Kol tidak terserang hama dan penyakit

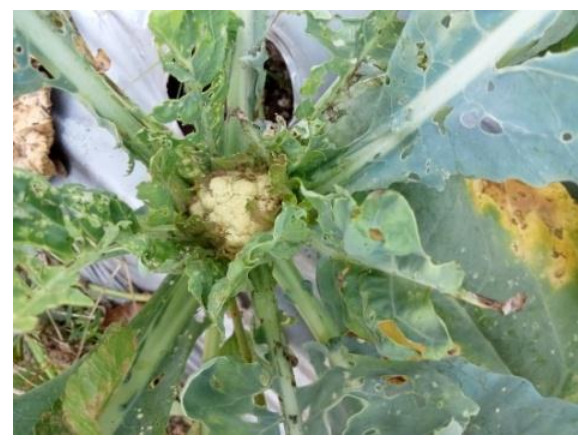

Gambar 6. Kondisi Bunga Kol terserang hama dan penyakit

Dari penelitian yang kami lakukan dengan menggunakan 3 sampel lahan bunga kol yang berbeda tempat didapat hama dan penyakit yang berbeda-beda. Ada yang kondisi bunga kolnya rusak karena terserang hama dan penyakit, kemudia ada bebrapa bunga kol yang tidak terserang penyakit.

\section{Populasi Hama Pada Lahan}

Untuk sampel lahan yang 1 didapat beberapa hama seperti belalang, kaper, laba-laba dan ulat bunga kol (Plutella xylostella) sedangkan penyakit yang menyerang ada beberapa bunga kol yang terkena penyakit ekor cambuk, namun sangat banyak sekali yang terserang busuk hitam dan lunak. Pada sampel lahan pertama ini petani mengakui bahwa mengalami kegagalan dikarenakan tidak dapat mengatasi hama dan penyakit yang menyerang bunga kol. Kondisi lahan bunga kol pada sampel lahan 1 daun bunga kol banyak berlubang dan banyak yang busuk. Sehingga hanya beberapa bunga kol yang layak untuk dipanen.

Untuk sampel lahan yang 2 didapat beberapa hama seperti kaper, laba-laba dan ulat bunga kol (Plutella xylostella) tapi jumlanya tidak sebanyak di lahan 1 , sedangkan penyakit yang menyerang ada beberapa bunga kol yang terkena penyakit ekor cambuk, namun sangat banyak sekali yang terserang busuk hitam dan lunak. Pada sampel lahan kedua ini petani mengakui bahwa mengalami kegagalan dikarenakan tidak dapat mengatasi hama dan penyakit yang menyerang bunga kol. Hama ini didapat karena lokasinya terletak dekat dengan lahan 1 sehingga hama dan penyakit mudah menular. Kondisi lahan bunga kol pada sampel 2 daun bunga kol banyak berlubang dan banyak yang busuk. Sehingga hanya beberapa bunga kol yang layak untuk dipanen seperti halnya pada lahan 1. Untuk sampel lahan yang 3 didapat beberapa hama seperti belalang, kaper, laba-laba dan ulat bunga kol ( Plutella xylostella) namun jumlahnya sedikit dan jarang ditemui, sedangkan penyakit yang menyerang bunga kol pada sampel lahan ini hanya ekor cambuk dikarenakan kondisi tanah yang mengandung asam berlebih. Pada sampel ketiga ini hama dan penyakit yang menyerang bunga kol tidak banyak. Kondisi lahan bunga kol pada sampel 3 ini sangat baik sehingga daun dan bunga kol tumbuh dengan baok.. Posisi lahan 3 ini sangat jauh dengan lahan pengamatan 1 san 2 sehingga hama dan penyakit yang menyerang bunga kol tidak banyak. Sehingga banyak bunga kol yang layak untuk dipanen. 


\section{a. Hama pada bunga kol yang diteliti:}

\section{1) Ulat Bunga Kol (Plutella xylostella)}

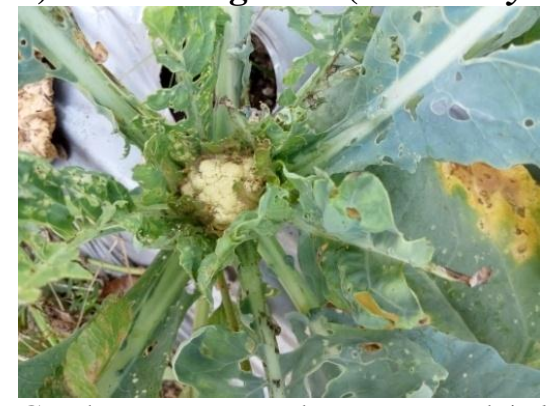

Gambar 7. Hama Ulat Bunga Kol (Plutella xylostella)

Hama ulat plutella bisa merupakan jenis hama yang paling banyak menyerang tanaman bunga kol. Warnanya hijau muda dengan panjang ukuran tubuh sekitar $0.5-1 \mathrm{~cm}$. Siklus hidupnya sendiri berkisar antara 10-14 hari, di mana saat dalam stadium larva ia akan terus memakan daun muda maupun tua pada bagian titik tumbuhnya. Serangan ulat plutella sering kali mendadak dan sulit diprediksi. Hal ini dikarenakan saat dewasa akan meletakkan telur-telurnya di bagian bawah daun. Sehingga seringkali kerusakan yang diakibatkan oleh larva-larva yang telah menetas sifatnya mendadak. Sama seperti halnya hama ulat jengkal, ulat plutella bisa dibasmi secara biologis dengan menggunakan bakteri Bacillus thuringiensis. Untuk itu, solusi yang paling ampun untuk mengurangi dampak serangan hama ulat plutella adalah dengan pencegahan sedini mungkin, dengan menanam refugia dan menggunakan prinsip budidaya polikultur maupun tumpang sari.

\section{2) Laba-laba}

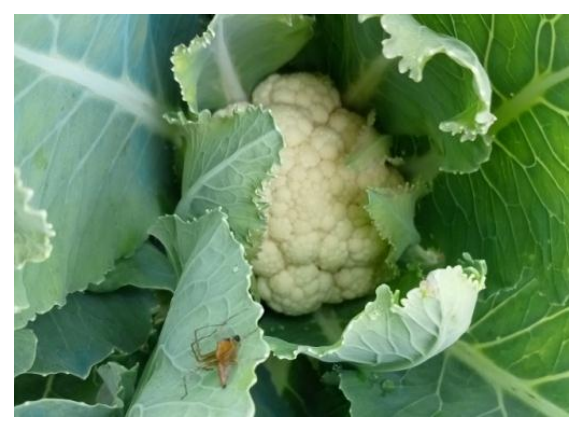

Gambar 8. Hama laba- laba

Laba-laba berukuran kurang dari 1 per 60 inci panjangnya. Memegang selembar kertas putih di bawah daun dan mengguncang tanaman adalah cara lain untuk mengungkapkan keberadaan mereka.karena laba-laba menggunakan bagian mulutnya untuk menyedot nutrisi dan cairan penting dari daun dan batang tanaman. Kita dapat melihat secara kasat mata dengan mengamati rangkaian titik-titik kuning pada daun yang berada di bundel. Ketika konsentrasi laba-laba sangat besar, ia akan mengering dan segalanya. Kebanyakan dari mereka biasanya hadir pada musim semi hingga musim gugur, ketika suhu lebih tinggi. Jika infestasi dibiarkan berkembang, pertumbuhan terhambat dan kematian kemungkinan besar terjadi. Hama tanaman ini cukup berbahaya karena menyerang bagian daun dengan cara menyerap cairan dan unsur hara tanaman. Penanggulangan hama ini karena lebih kebal terhadap insektisida, disarankan untuk membasmi hama tanaman ini menggunakan akarisida, yaitu bahan senyawa kimia beracun yang ampuh membunuh rumpun keluarga tungau, caplak dan laba-laba.

\section{3) Belalang}

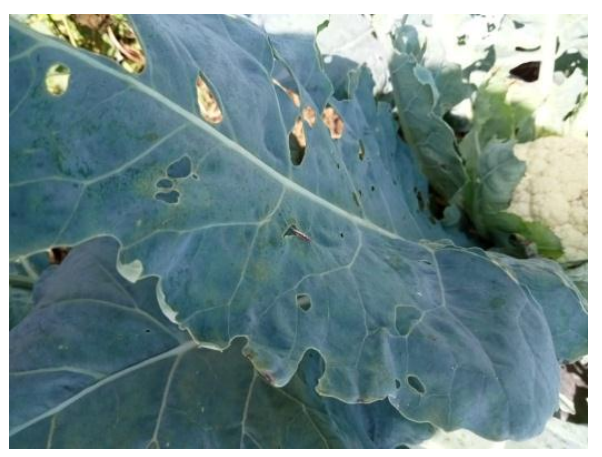

Gambar 9. Hama Belalang

Belalang adalah serangga herbivora yang terkenal sebagai hama dengan kemampuan melompat mumpuni (dapat mencapai jarak hingga 20 kali panjang tubuhnya). Pada umumnya belalang berwarna hijau atau cokelat. Serangan hama tersebut mengakibatkan dedaunan tanaman tersebut habis dimakan. Membasmi belalang bisa dilakukan dengan cara menangkap atau menyemprot dengan air menggunakan penyiram tanaman supaya hama tanaman ini sulit terbang dan bisa dienyahkan. Selain itu, gunakan saja pestisida organik atau alami racikan karena umumnya sudah cukup untuk mengusirnya. 


\section{4) Kaper}

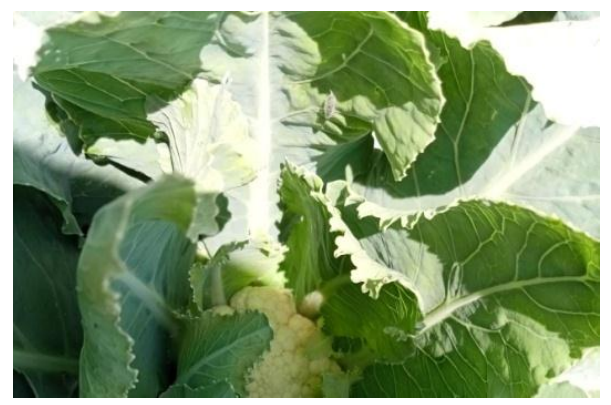

Gambar 10. Hama Kaper

Serangga kecil yang banyak sekali terdapat di kebun bunga kol. Hama ini dapat dikendalikan dengan parasitoid, clotesia glomerata menyerang larva. Dan juga mengakibatkan daun-daun bunga kol menjadi berlubang. Cara penangulanganya yaitu dengan menggunakan produk-produk yang mengandung bakteri alami, Bacilus Thuringiensis atau sacchatopholyspora spinosa (spinosad) sangat efektif ketika disemprot kan secara menyeluruh pada permukaan daun atas dan bawah. Namun insektisida ini tidak bertahan lama di lingkungan. Dalam pengendalian kaper secara kimiawi akan lebih baik ketika dalam insektisida mengandung bahan aktif phyrethrum, Lambada chyhalotrin yang dapat digunakan pula untuk mengendalikan ulat bulu.

\section{b. Penyakit pada bunga kol yang diteliti:}

\section{1) Ekor Cambuk}

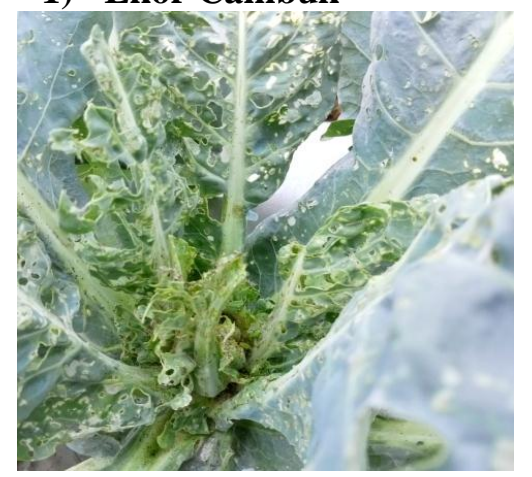

Gambar 11. Penyakit Ekor Cambuk

Penyakit jenis ekor cambuk biasanya bentuk daun akan berubah menjadi seperti ekor cambuk. Biasanya pertumbuhan pada kepala bunga akan terganggu yang mengakibatkan kualitas produksi menjadi tidak maksimal. Hal ini disebabkan karena kondisi tanah yang mengandung asam

\section{2) Busuk Hitam}

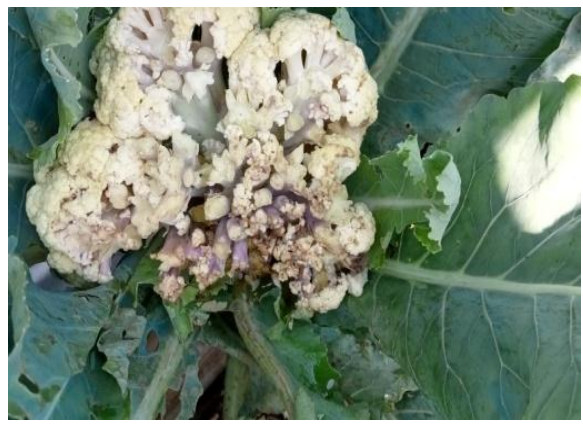

Gambar 12. Penyakit Busuk Hitam

Gejala penyakit busuk hitam seperti ini sesuai dengan yang ditimbulkan oleh bakteri Xanthomonas campextris Dows, sebagaimana yang dijelaskan oleh Alvares et al., (1994) gejala penyakit yang ditimbulkan bakteri ini pada tanaman kubis antara lain, daun tanaman berbentuk huruf $\mathrm{V}$ yang diikuti oleh nekrosis, Xanthomonas sp. Merupakan salah satu bakteri penyebab penyakit busuk hitam pada tanaman Brassicas (Wolf, 2005). Gejala penyakit busuk hitam pada fase generatif adalah terdapat busuk dan warna hitam pada massa bunga kol. Hasil pengamatan di lapangan pada umumnya massa bunga yang terserang lebih dulu adalah bagian tajuk tengah, kemudian menyebar ke seluruh massa bunga kol. Mula-mula massa bunga yang terserang akan berwarna kuning muda hingga kuning tua, kemudian berwarna orange, dan berkembang menjadi warna hitam di ikuti pembusukan. Sastrosiswojo et al., (2005) mengatakan penyakit ini di tandai oleh munculnya bercak coklat kehitam-hitaman pada daun, batang, dan tangkai bunga. Gejala khas pada daun adalah tampaknya warna kuning kecoklat-coklatan dan kemudian mongering. Batang atau massa bunga yang terserang umumnya menjadi busuk dan berwarna hitam atau coklat sehingga kurang layak untuk dipanen.

Xanthomonas campextris Dows menyebar melalui Sees borne (Bradbury, 1986). Bakteri ini dapat menyerang kelompok tanaman kubis pada semua tingkat pertumbuhan dan perkembangan (Semangun, 2004). Pada waktu persemaian tanaman kol, patogen ini mengakibatkan rebah kecambah (damping off), karena infeksi awalnya 
terjadi pada kotiledon dan kemudian menjalar ke seluruh bagian tanaman (Wolf, 2005).

Bunga kol yang terserang sebelum disimpan daun-daun yang terinfeksi dibuang dan dimusnahkan serta batang bekas potongan diolesi dengan cairan klorin. Agar tidak menular ke bunga kol lainnya, berlebih, cara mengatasinya dengan memberikan kapur pada lahan tanam.

\section{3) Busuk Lunak}

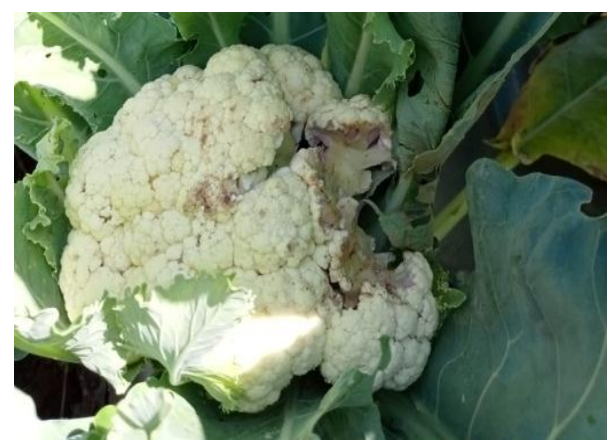

Gambar 13. Penyakit Busuk Lunak

Busuk Lunak disebabkan karena bakteri Erwinia carotovora Holland. Penyakit ini menyebabkan busuk lunak pada tanaman di kebun dan pasca panen. Infeksi terjadi setelah busuk lunak melalui luka pada pangkal bunga yang hampir dipanen atau melalui akar yang terluka. Hal ini sesuai dengan gejala serangan ditandai dengan munculnya bintik bintik kecil berwarna kecoklatan di permukaan daun. Bercak-bercak kecil berair tersebut kemudian berkembang menjadi kecoklatan dan mengeluarkan bau busuk (Hakim, 2010). Pada serangan lanjut, daun yang terinfeksi melunak, berlendir dan mengeluarkan bau yang khas (Sagala, 1998). Hal ini juga menyebabkan tanaman kerdil, layu dan mati.Bakteri busuk lunak dapat timbul dari seresah tanaman yang telah terinfeksi, melalui akar tanaman, dari tanah, dan beberapa serangga. Luka pada tanaman seperti stomata pada daun, serangan serangga, kerusakan mekanis, ataupun bekas serangan dari patogen lain merupakan sasaran yang empuk untuk serangan bakteri (Agrios,2005). Akibat dari hal tersebut, jaringan yang terinfeksi kemudian membesar, melunak, berubah warna, berlendir kemudian mengeluarkan bau yang busuk yang ditimbulkan oleh bakteri $E$. carotovora. Gelajanya dimuali dari busuknya batang atau pangkal bunga dengan tiba-tiba. Bunga kol yang terserang sebelum disimpan daun-daun yang terinfeksi dibuang dan dimusnahkan serta batang bekas potongan diolesi dengan cairan klorin.

\section{Kesimpulan}

Berdasarkan hasil penelitian dapat disimpulkan bunga kol adalah jenis tanaman yang kesulitanya sedang. Dikareanakan hama dan penyakit sulit diprediksi oleh petani. Pada penelitian ini didapat hama kaper sangat banyak dan dari petani belum dapat mengatasi hama ini sehingga hasol panen bunga kol todak maksimal dan mengalami penurunan. Berdasarkan permasalahan diatas dan mengingat tanaman bunga kol menjadi tanaman penting karna bukan saja sebagai sayur-sayuran namun ada mengonsumsi sebagai obat, maka penelitian ini dilakukan untuk mengidentifikasi secara jelas jenis hama dan penyakit yang menyerang sayur bunga kol, Selain itu dengan adanya penelitian ini diharapkan mampu membawa kebermanfaatan kepada masyarakat khususnya dalam menghadapi tantangan-tantangan dalam menanam bunga kol.

\section{Ucapan Terima Kasih}

Ucapan terima kasih disampaikan kepada Program Studi Pendidikan Biologi Fakultas Keguruan dan Ilmu Pendidikan telah membiayai penelitian dana hibah anggaran Program Studi Pendidikan Biologi 2021. Selain itu terimakasih kepada Bu Dra. Nur Rokhimah H, M. P yang telah membimbing dalam penelitian ini.

\section{Referensi}

Anonim. A. (2009). Teknologi Budidaya Tanaman Pangan. http://iptek.net.id_pangan/index.phd?id=2 03.

Chakravarty (2012). "Biocontrol Potential of Pseudomonas fluorescens Agains Bacterial Wilt of Brinjal and Its Possible Plant Grownt Promoting Efects". Annal of Biological Research, 3 (11): 50835094.www.scholarsreseachlibrary.com.

Damanik (2013). “Uji Efikasi Agens Hayati Terhadap Penyakit Hawar Daun Bakteri 
(Xanthomonas oryzaepv. Oryzae) Pada Beberapa Varitas Padi Sawah (Oryza sativa).Jurnal online agroekoteknologi.

Herlinda, S. (2003). Ecology of Diamonback moth Plutella Xellostela L. (Lepidhoptella: Plutellidae) on mustard (Brasicca juncea Coss) in low land area of south Sumatra. Didalam Prosiding Inernatinal seminar \& exhibition on prospectif of low land Development in Indonesia. Palembang, 8-9 Desember 2003. Palembang: Sriwijaya University Publishers, Inc. hlm 100-105.

Herlinda, S. (2004). Dinamika Interaksi antara parasitoid dengan inangnya, Plutella Xylostella L. (Lepidhoptella: Plutellidae) pada Tanaman Brasicaceae. Agria 1: 1017.

Herlinda, S., Rosdah Thalib, \& R. M. Saleh. (2004). Perkembangan dan preferensi Plutella Xvlostella (Lepidhoptera: Ypononomeutidae) pada tanaman kubis (Brasicacedae) 1: 10-17.

Kartini E, (2014). Pengembangan BioBakterisida yang Memanfaatkan Bahan Aktif Bakteri Endofit Potensial Antagonis untuk mengendalikan Erwinia Sp., di Umbi Kentang. Jurnal HPT, 2(4).

Lumoy F.S., Senewe E., \& Manengekey G. S. J. (2016). Insiden Penyakit Busuk Hitam pada Tanaman Brokoli (Brasicca oleracea var. Italica) di Tomohon. Fakultas Pertanian. Universitas Sam Ratulangi

Rukmana (1994). Budidaya Kubis Bunga dan Brokoli. Penerbit Kanisius. Yogyakarta.http://budidayanews.blogspot .co.id/2011/06/budidaya-kembangkol.html.

Runtukahu. J. O. (2016). Evektivitas Trocoderma sp. Metabolic dan Pseudomonas fluorescens Terhadap Penykit Busuk Lunak pada Tanaman Kol Bunga (Brasica oleracea var. Botrytis L.). Fakultas Pertania UNSRAT.
Sagala, U.S., (1998). Uji Potensi Antagonisme Pseudomonas fluorescens (Isolat UKa dan UKd) terhadap Erwinia carotovora pv. carotovora Penyebab Penyakit Busuk Lunak pada Tanaman Kubis (Brassica oleracea var. capitata L.). diakses dari http://repository.ipb.ac.id/.

Sastrosiswojo (2005). "Penerapan Teknologi PHT Pada Tanaman Kubis. Bandung: Balai Penelitian Tanaman Sayuran.

Sembel, D.T. (2010). Pengendalian HayatiHama-hama Serangga Tropis dan Gulma. Andi. Ofset. Yogyakarta.

Semangun, H. (2007). Penyakit-Penyakit Tanaman Holtikultura di Indonesia. Edisi II. Yogyakarta: Gadjah Mada University press.

Soesanto L. (2011). "Kajian Aplikasi Formula Cair Pseudomonas fluorescens p60 Terhadap Penyakit Layu Bakteri Serta Pertumbuhan Dan Hasil Tanaman Kentang”.Fakultas pertanian unsoed.

Sunarti (2017). Pengamatan Hama dan Penyakit Penting Tanaman Kubis Bunga (Brasicca oleracea ver. Botrytis L.). Fakultas Pertanian Universitas Prof. Dr. Hazairin. Bengkulu.

Untung, K. (2006). Pengantar Pengelolaan Hama Terpadu. Gadjah Mada University Press. Yogyakarta.

Wolf, J. V.D. (2005). Infection of Brassica seed with Xanthomonas campextris pv, campestris. Plant Research International: 19-28.

Wulansari N. (2015). “Upaya Pengendalian Penyebab Penyakit Busuk Hitam Pada Tanaman Brokoli (Brassica oleraceavar. Italica) Dengan Antagonisnya. Universitas Udayana Denpasar. 